\title{
Genotoxic potential of selected medicinal plant extracts in human whole blood cultures
}

\author{
Karina Harutyunyan $^{1}$, Karine Balayan², Gohar Tadevosyan ${ }^{3}$, Manush Hayrapetyan $^{1}$, Ruzanna Musayelyan ${ }^{1}$, \\ Ruzanna Grigoryan $^{3}$, Lusine Khondkaryan ${ }^{3}$, Natalya Sarkisyan ${ }^{3}$, Nelly Babayan $^{3,4^{*}} \mathbb{D}$ \\ ${ }^{1}$ Artsakh Scientific Centre, Stepanakert, RA \\ ${ }^{2}$ Department of Biology, Artsakh State University, Stepanakert, RA \\ ${ }^{3}$ Group of Cell Technologies, Institute of Molecular Biology, National Academy of Sciences, Yerevan, RA \\ ${ }^{4}$ Department of Genetics and Cytology, Yerevan State University, Yerevan, RA
}

\section{AR T I C L E I N F O}

Article Type:

Short Communication

\section{Article History:}

Received: 16 August 2018

Accepted: 16 November 2018

\section{Keywords:}

Medicinal plants

Herbal medicine

Leaf extracts

Cell viability

Micronucleus

Genotoxicity

\begin{abstract}
A B S T RA C T
Introduction: Many plant-derived products despite wide usage are not scientifically evaluated for their safety and efficacy. Therefore, in the present study, we aimed to evaluate the cytotoxic and genotoxic activities of Polygonum aviculare L., Equisetum arvense L., Plantago lanceolata L. and Artemisia absinthium L. ethanolic extracts in human white blood cells.

Methods: Cell viability was assayed by trypan blue exclusion method, while the genotoxicity was tested by cytokinesis-block micronucleus (CBMN) assay upon cells stimulation with noncytotoxic concentrations of the plant extracts.

Results: None of the plant extracts showed high cytotoxic activity. At the same time, only extract of $P$. lanceolata did not present any mutagenic activity, while E. arvense, $P$. aviculare and A. absinthium were clearly genotoxic.

Conclusion: Caution is advice in the case of long-term use of E. arvense, P. aviculare and A. absinthium herbal medicines by population.
\end{abstract}

Implication for health policy/practice/research/medical education:

Equisetum arvense, Polygonum aviculare and Artemisia absinthium extracts exhibited genotoxic effects, and may represent hazards to human health. Thus, our findings raise concern about their safety, especially during long-term application.

Please cite this paper as: Harutyunyan K, Balayan K, Tadevosyan G, Hayrapetyan M, Musayelyan R, Grigoryan R, et al.Genotoxic potential of selected medicinal plant extracts in human whole blood cultures. J Herbmed Pharmacol. 2019;8(2):160162. doi: $10.15171 /$ jhp.2019.25.

\section{Introduction}

The increasing demand for novel therapeutics as antimicrobial and anti-inflammatory agents, resurgence the interest towards medicinal plants. Based on their longterm application, there is general perception that herbal remedies are safe. Nonetheless, growing data suggest that medicinal plants can cause severe adverse effects, including mutagenic and genotoxic activities, thus raising concerns about their potential hazards to human health (1). Consequently, studies on plant extracts genotoxic effects are of primary importance to assess the potential risks, particularly during long-term usage.

Polygonum aviculare L., Equisetum arvense L., Plantago lanceolata L., and Artemisia absinthium L. are common medicinal plants used worldwide to treat infectious diseases, chronic inflammatory conditions and externally for wounds healing $(2,3)$. A. absinthium is very popular as an anti-helmintic agent, choleretic and appetizer (2). Despite popularity, data on their safety are scanty. Thus, in the present study we aimed to evaluate the cytotoxic and genotoxic activities of the leaf extracts of $P$. aviculare, $E$. arvense, $P$ lanceolata and $A$. absinthium in human whole blood cells.

\section{Materials and Methods}

Plantago aviculare L., E. arvense L., P. lanceolata L. and A. absinthium L. were collected throughout NagornoKarabakh, identified using appropriate literature (4) and voucher specimens were deposited at the Artsakh Scientific Centre, Nagorno-Karabakh, RA (ASC00013, 
ASC00016, ASC00025, ASC00032, respectively).

The leaves were detached from the collected materials, washed, dried and finely powdered. Powdered samples were mixed with ethanol (1:10) and incubated in the dark with occasional shaking. Afterwards, the filtrates were evaporated under reduced pressure using the rotary evaporator and received crude extracts were dissolved in dimethyl sulfoxide (DMSO, Sigma-Aldrich, USA) at concentration of $100 \mathrm{mg} / \mathrm{mL}$ and kept at $-20^{\circ} \mathrm{C}$ until used for biological assays.

Venous blood was collected from three healthy volunteers by venepuncture into sterile heparinized tubes (Vacuette, Greiner Bio-One). All study participants provided written informed consent. The study was designed according to the ethical guidelines of the Helsinki Declaration and was approved by the ethics committee of the Institute of Molecular Biology of NAS RA (IRB \# IORG0002437).

$200 \mu \mathrm{L}$ of blood was cultivated in $600 \mu \mathrm{L}$ of Roswell Park Memorial Institute medium (RPMI) supplemented with $10 \%$ fetal bovine serum (FBS), $2 \mathrm{~mm}$ L-glutamine, $100 \mathrm{ED} / \mathrm{mL}$ penicillin and $100 \mathrm{mg} / \mathrm{mL}$ streptomycin in the presence of plant extracts at final concentrations ranging from $100 \mu \mathrm{g} / \mathrm{mL}$ to $2000 \mu \mathrm{g} / \mathrm{mL}$ and incubated at $37^{\circ} \mathrm{C}$ and $5 \% \mathrm{CO}_{2}$ for 24 hours. Untreated cells and DMSO (1\%) treated cells served as negative and solvent controls, respectively. After stimulation, contaminating red blood cells were removed with ammonium chloride lysis buffer, remaining cells were washed with phosphate buffered saline (PBS) and stained with 0.4\% Trypan blue solution. The number of live/dead cells was counted under a light microscope using a hemocytometer. Cell viability was expressed as a percentage of the negative control. Samples that gave cell viability above $90 \%$ were considered nontoxic for blood white cells.

For cytokinesis-block micronucleus (CBMN) assay $1 \mathrm{~mL}$ of blood was added to $10 \mathrm{~mL}$ of RPMI supplemented $10 \%$ FBS, $2 \mathrm{~mm}$ L-glutamine, $100 \mathrm{ED} / \mathrm{mL}$ penicillin and 100 $\mathrm{mg} / \mathrm{mL}$ streptomycin and PHA $(10 \mu \mathrm{g} / \mathrm{mL})$ and cultured for 44 hours at $37^{\circ} \mathrm{C}$ and $5 \% \mathrm{CO}_{2}$. Afterwards, nontoxic concentrations of plants extracts were added. Untreated cells and DMSO-treated samples were used as negative and solvent control, respectively. Mytomicin $(0.1 \mu \mathrm{g} / \mathrm{mL})$ treated cells served as positive control. Cytochalasin B ( $6 \mu \mathrm{g} / \mathrm{mL}$, Sigma- Aldrich Co., USA) was added to the cultures 4 hours after the treatment substance was added and cultures were incubated for another 22 hours. At 72 hours, the cells were harvested and subjected to a mild hypotonic treatment with potassium chloride solution, fixed twice with methanol:acetic acid (3:1), smeared on a precleaned microscope slides and air-dried. Staining was performed with Giemsa (10\%), and each slide was coded to allow for a blinded evaluation. A total of 1000 binucleated cells $(\mathrm{BN})$ were scored and the frequency of binucleated cells with micronuclei (MN) was determined, as previously described (5).

Data analysis was performed with GraphPad Prism 5.01 (GraphPad Software, USA). All experiments were conducted in triplicates. Values were expressed as means \pm SE. Data were analyzed by repeated measures ANOVA and differences between groups were determined by Dunn's post hoc test. $P<0.05$ was considered as the statistically significant value.

\section{Results}

As evident from Figure 1A extracts of $P$. aviculare and $P$. lanceolata did not affect cell viability at any concentration tested. In contrast, treatment with extracts of $A$. absinthium and E. arvense resulted in dose-dependent reduction in cell viability (Figure $1 \mathrm{~B}$ ), though only at 2000 $\mu \mathrm{g} / \mathrm{mL}$ concertation a decrease in cell viability by $<50 \%$ was observed.

The results of CBMN assay are presented in Table 1 . Among tested extracts, only $P$. lanceolata did not exhibit any genotoxic damage, while extracts of $P$ aviculare and $A$. absinthium produced strong mutagenic effects, significantly increasing the micronucleus frequency $\mathrm{MN}$ as compared to the negative control $(P<0.01)$. Similarly, 4-fold increase in incidence of $\mathrm{MN}$ was found upon treatment of cells with E. arvense extracts, though it did not reach statistical significance.

\section{Discussion}

Plant extracts represents the complex mixture of various constituents and many of them are potentially toxic (6).

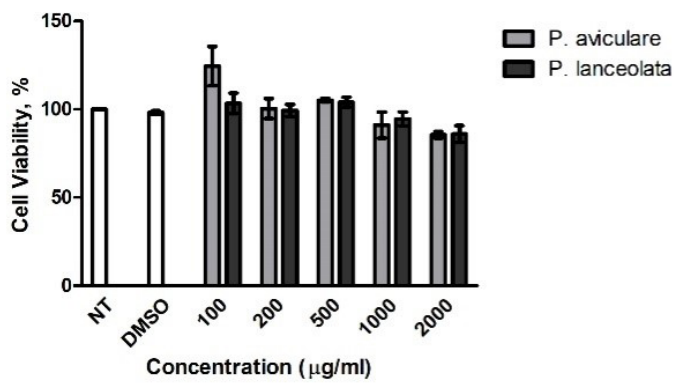

B

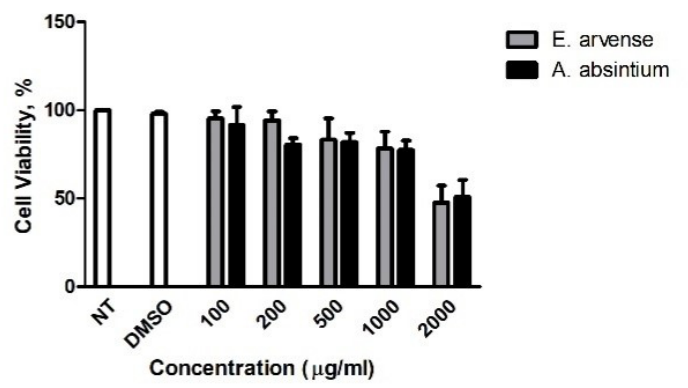

Figure 1. Percentage of viable cells after $24 \mathrm{~h}$ exposure of whole blood cells to various concentrations $(\mu \mathrm{g} / \mathrm{mL})$ of $P$. aviculare, $P$. lanceolata (A), E. arvense and $A$. absinthium (B) extracts assessed by Trypan blue exclusion method. Results are presented as mean \pm standard error (SE). ${ }^{*} P<0.05$ vs untreated samples. 
Table 1. Micronucleus frequency (MN) in peripheral blood cells exposed to nontoxic concentrations of ethanolic extracts of Plantago lanceolata, Equisetum arvense, Polygonum aviculare and Artemisia absinthium

\begin{tabular}{lcc}
\hline Substance & $\begin{array}{c}\text { Concentration } \\
(\mu \mathrm{g} / \mathrm{mL})\end{array}$ & $\begin{array}{c}\text { Frequency of } \\
\text { MN/1000BN } \\
\mathrm{N}\end{array}$ \\
\hline Negative control & & $3 \pm 0.6$ \\
DMSO & & $5 \pm 0.6$ \\
Positive control (mytomicin) & 0.1 & $39 \pm 3.04^{* * *}$ \\
P. lanceolata & 500 & $4.2 \pm 0.8^{\# \#}$ \\
E. arvense & 100 & $12.7 \pm 1.0 .9$ \\
P. aviculare & 500 & $20.2 \pm 1.8^{* *}$ \\
A. absinthium & 100 & $17 \pm 0.9^{*}$ \\
\hline Results are presented asmean & &
\end{tabular}

Results are presented as mean $\pm \mathrm{SE}$. ${ }^{*} P<0.05,{ }^{*} * P<0.01, * * * P<0.01$ vs negative control; ${ }^{\#} P<0.01$ vs positive control.

Therefore, the development of herbal medicinal products requires toxicological evaluation. In the present study, under our experimental conditions, none of the extracts showed high levels of cytotoxic activity. At the same time, only $P$. lanceolata did not exhibit any genotoxic effect towards human white blood cells. In line with our results, no mutagenic effects were observed for ethanolic extracts of $P$. lanceolata by means of induction of somatic segregation in Aspergillus nidulans and the Ames-test $(1,7)$. The genotoxic assessment of E. arvense showed contrasting results. Kour et al (8) have reported no mutagenic effect in mice bone marrow cells treated with $E$. arvense ethanolic extract, while increase in MN frequency has been reported in human lymphocytes $(9,10)$. We found even higher incidence of $\mathrm{MN}$ in response to treatment with E. arvense as compared to previous studies, which may be attributed to the differences in the extract preparations or to secondary metabolites composition impacted by environment (11). Despite promising nature of $P$. aviculare and $A$. absinthium as anti-inflammatory, antioxidative and antibacterial agents (12-14), there is lack of toxicological assessment of these plants. Our results suggested that both plant extracts were highly genotoxic, which rise concerns about the potential biosafety of these medicinal herbs.

In conclusion, our results indicate that $P$. lanceolata ethanolic extract can be freely used in alternative medicine. However, caution is needed in case of E. arvense, $P$. aviculare and $A$. absinthium preparations, due to their genotoxic potential. Although these medicinal plants are promising, further studies are necessary to establish safe doses of their use.

\section{Authors' contributions}

$\mathrm{KH}, \mathrm{RM}, \mathrm{MH}, \mathrm{GT}, \mathrm{RG}$ and NS performed the experiments. $\mathrm{KB}$ collected and identified plants. KL, GT and NB contributed to experiments design, statistical analysis and the manuscript drafting. All authors read and confirmed final version of the manuscript for publication.

\section{Conflict of interest}

The authors report no potential conflict of interest.

\section{Ethical considerations}

This study was approved by the ethics committee of the Institute of Molecular Biology of NAS RA (IRB \# IORG0002437) and all experiments were carried out in accordance to the ethical guidelines of the Helsinki Declaration.

\section{Funding/Support}

This work was supported by the RA MES State Committee of Science, in the frames of the research project № 16AA04 .

\section{References}

1. Schimmer O, Kruger A, Paulini H, Haefele F. An evaluation of 55 commercial plant extracts in the Ames mutagenicity test. Pharmazie. 1994;49(6):448-51.

2. Gruenwald J, Brendler T, Jaenicke C. PDR for Herbal Medicines. 2nd ed. New Jersey, USA: Medical Economics Company Inc; 2000:588.

3. van Wyk BE, Wink M. Medicinal plants of the world. 1st ed. Oregon, USA: Timber Press Inc; 2005:479.

4. Grossheim A. A field guide to plants of Caucasus. 1st ed. Moscow, USSR: Sovetskaya Nauka; 1949:376.

5. Fenech $M$. The in vitro micronucleus technique. Mutat Res. 2000;455(1-2):81-95.

6. Moreira Dde L, Teixeira SS, Monteiro MHD, De-Oliveira ACAX, Paumgartten FJR. Traditional use and safety of herbal medicines1. Rev Bras Farmacogn. 2014;24(2):24857. doi: 10.1016/j.bjp.2014.03.006.

7. Ramos Ruiz A, De la Torre RA, Alonso N, Villaescusa A, Betancourt J, Vizoso A. Screening of medicinal plants for induction of somatic segregation activity in Aspergillus nidulans. J Ethnopharmacol. 1996;52(3):123-7.

8. Kour J, Ali MN, Ganaie HA, Tabassum N. Amelioration of the cyclophosphamide induced genotoxic damage in mice by the ethanolic extract of Equisetum arvense. Toxicol Rep. 2017;4:226-33. doi: 10.1016/j.toxrep.2017.05.001.

9. Milovanovic V, Radulovic N, Todorovic Z, Stankovic M, Stojanovic G. Antioxidant, antimicrobial and genotoxicity screening of hydro-alcoholic extracts of five Serbian Equisetum species. Plant Foods Hum Nutr. 2007;62(3):1139. doi: 10.1007/s11130-007-0050-z.

10. Joksic G, Stankovic M, Novak A. Antibacterial medicinal plants Equiseti herba and Ononidis radix modulate micronucleus formation in human lymphocytes in vitro. J Environ Pathol Toxicol Oncol. 2003;22(1):41-8.

11. Ramakrishna A, Ravishankar GA. Influence of abiotic stress signals on secondary metabolites in plants. Plant Signal Behav. 2011;6(11):1720-31. doi: 10.4161/psb.6.11.17613.

12. Craciunescu O, Constantin D, Gaspar A, Toma L, Utoiu E, Moldovan L. Evaluation of antioxidant and cytoprotective activities of Arnica montana L. and Artemisia absinthium L. ethanolic extracts. Chem Cent J. 2012;6(1):97. doi: 10.1186/1752-153x-6-97.

13. Granica S, Czerwinska ME, Zyzynska-Granica B, Kiss AK. Antioxidant and anti-inflammatory flavonol glucuronides from Polygonum aviculare L. Fitoterapia. 2013;91:180-8. doi: 10.1016/j.fitote.2013.08.026.

14. Habibipour R, Rajabi M. Antibacterial effects of Arctium lappa and Artemesia absinthium extracts in laboratory conditions. J Herbmed Pharmacol. 2015;4(4):133-7. 